УДК 378.14

\title{
ТАЙМ-МЕНЕДЖМЕНТ СТУДЕНТСТВА В УМОВАХ ПАНДЕМIÏ COVID-19
}

\section{STUDENT TIME MANAGEMENT IN THE CONVENTION OF THE COVID-19 PANDEMIC}

\author{
Манаєнко Ірина Миколаївна \\ кандидат економічних наук, доцент, \\ Національний технічний університет України \\ «Київський політехнічний інститут імені Ігоря Сікорського» \\ ORCID: https://orcid.org/0000-0002-3246-3603 \\ Матіяш Дар'я Олександрівна \\ студентка, \\ Національний технічний університет України \\ «Київський політехнічний інститут імені Ігоря Сікорського» \\ ORCID: https://orcid.org/0000-0003-1177-6624
}

Manaienko Iryna, Matiiash Daria
National Technical University of Ukraine
"Igor Sikorsky Kyiv Politechnic Institute"

Дана стаття присвячена характеристиці основних проблем сучасної молоді пов'язаних із плануванням свого часу в умовах світової пандемії. Для того, щоб краще зрозуміти суть статті, було наведено основну інфрормацію, яка стосується теми тайм-менеджменту. Особлива увага приділяється методам та технікам таймменеджменту, які допомагають нам краще та більш ефективно планувати та управляти своїм часом. В статті аналізується те, на скільки раціонально опитані студенти використовують власний час. По-перше, досліджується основний компонент тайм-менеджменту - планування, та його способи: запис справ як в офлайн фрорматі, так і в онлайн форматі. По-друге, проводиться аналіз того, де ми втрачаємо час, та чому його може нам не вистачати. Йдеться мова про використання гаджетів, саморозвиток, домашні завдання, прокрастинація тощо. У статті наведені також й інші чинники, які значно впливають на те, як ми ефективно використовуємо власний час: неправильно розподілений час, «пожирачі часу». У ході дослідження було виявлено рівень продуктивності опитаних студентів та те, чи вони все встигають за 24 години в добі. Також наведено можливі шляхи подолання проблем, пов'язаних із нестачею часом. Актуальність даної статті полягає в аналізі рівня організованості студентів-респондентів протягом дня, оскільки час - це дуже важливий ресурс у нашому життя, який потрібно використовувати з обережністю та бути більш зваженим і розумним під час розстановки пріоритетів, особливо у умовах дистанційної освіти за часів світової пандемії.

Ключові слова: використання часу, планування, показник, студенти, тайм-менеджмент, чинники.

Данная статья посвящена характеристике основных проблем современной молодежи связанных с планированием своего времени в условиях мировой пандемии. Для того, чтобы лучше понять суть статьи, было приведено основную информацию, касающуюся темы тайм-менеджмента. Особое внимание уделяется методам и техникам тайм-менеджмента, которые помогают нам лучше и больше эффективно планировать и управлять своим временем. В статье анализируется то, насколько рационально опрошенные студенты используют собственное время. Во-первых, исследуется основной компонент тайм-менеджмента - планирование, и его способы: запись дел как в офффлайн формате, так и в онлайн фрормате. Во-вторых, проводится анализ того, где мы теряем время, и почему его может нам не хватать. Идет речь об использовании гаджетов, саморазвитие, домашних заданиях, прокрастинации и тому подобное. В статье приведены также и другие фракторы, которые значительно влияют на то, как мы эффеективно используем собственное время: неверно распределенное время, «пожиратели времени». В ходе исследования был выявлен уровень производительности опрошенных студентов и то, ли они все успевают за 24 часа в сутках. Также приведены возможные пути преодоления проблем, связанных с нехваткой времени. Актуальность данной статьи заключается в анализе уровня организованности студентов-респондентов в течение дня, поскольку время - это очень важный ресурс в нашей жизни, который нужно использовать с осторожностью и быть 
более взвешенным и разумным во время расстановки приоритетов особенно в условиях дистанционного образования во времена мировой пандемии.

Ключевые слова: использование времени, планирования, показатель, студенты, тайм-менеджмент, фракторы.

This article is devoted to the characteristics of the main problems of modern youth related to the planning of their time in a global pandemic. In order to better understand the essence of the article, the basic information related to the topic of time management was given, namely the essence and role of the concept of "time management". Particular attention is paid to time management methods and techniques that help us better and more effectively plan and manage our time. Among them are the following: "Tomato Method", also called "25 Minute System", invented by Francesco Cirillo, "Eat a frog for breakfast", which focuses on unpleasant matters, and the elephant method, which means doing large tasks at first. The article analyzes how rationally interviewed students use their own time, because in connection with the pandemic, in our country a distance learning regime was introduced and students had a problem with the correct distribution of their time. First, the main component of time management is studied planning and ways to implement it. This can be a case recording in both offline and online format. Secondly, an important issue is the duration of sleep. Third, we analyze where we waste time and why we may lack it. We are talking about the use of gadgets, self-development, homework, procrastination and more. The article also lists other factors that significantly affect how we use our time effectively: incorrectly allocated time, inappropriately prioritized tasks, the influence of "time eaters", such as social networks, gadgets. The study revealed the level of productivity of the surveyed students and whether they keep up in 24 hours a day. There are also possible ways to overcome the problems associated with lack of time and tips on how to use time wisely during distance learning in connection with the COVID-19 pandemic. The relevance of this article is to analyze the level of organization of student respondents during the day, because time is a very important resource in our lives that should be used with caution and be more balanced and reasonable when setting priorities, especially in distance education during a global pandemic.

Keywords: use of time, planning, indicator, students, time management, factors.

Постановка проблеми. В умовах світової пандемії COVID-19 стало очевидним що, час - це найбільш важливий ресурс, якого нам завжди не вистачає. Насправді, ніхто ніколи не задумувався над тим, скільки часу ми витрачаємо на ту чи іншу справу протягом свого життя. Саме тому для того, щоб стати успішним в усіх сорерах свого життя, необхідно знати, як правильно розпоряджатися своїм часом. Тому тут доцільно говорити про тайм-менеджмент, тобто управління власним часом із максимальною есрективністю. Управління часом може допомогти шляхом ряду навиків, інструментів і методів, що використовуються при виконанні конкретних завдань, проектів і цілей. Цей набір включає широкий спектр діяльності, a саме: планування, розподіл, постановку цілей, делегування, аналіз витрат часу, моніторинг, організація, складання списків і розставляння пріоритетів тощо. Аби оцінити те, на скільки раціонально людина використовує свій час, створено багато тестів, опитувань тощо. Автори даної статті провели оцінювання на тему «Тайм-менеджмент одного дня» серед студентів КПІ імені Ігоря Сікорського, метою якого було з'ясувати рівень організованості та продуктивності студентів протягом дня в умовах дистанційної освіти зумовленої світовою пандемією COVID-19.

Аналіз основних дослідженнь та публікацій. Питання управлінню часом, або тайм-менеджменту присвячена низка науково-методичних, аналітичних та практич- них досліджень. Проблематику даної статті вивчали Д. Адаїр [1], Н. О. Алюшина [2], Г. А. Архангельський [3], В. Н. Куликова [4], Б. Трейсі [5], а також інші. У ході дослідження було використано декілька джерел. Десять 3 яких наводять нам основні відомості з теми «Тайм-менеджмент $[1 ; 2 ; 3 ; 4 ; 6 ; 7 ; 8 ; 10 ; 11]$. I ще одне джерело - це, безпосередньо, форма для опитування, на основі результатів якої був проведений аналіз [9].

Формулювання цілей статті. Метою проведення дослідження $€$ провести аналіз продуктивності та визначити есрективність використання власного часу протягом одного дня студентства на прикладі студентів КПІ імені Ігоря Сікорського умовах дистанційної освіти зумовленої світовою пандемією COVID-19. Наведені результати дозволять показати можливі шляхи вирішення проблем із нестачею часу та бути більш зваженим і розумним під час розстановки пріоритетів.

Виклад основного матеріалу. Час - це такий же ресурс, як і люди, природні ресурси, сировина, фрінансові засоби. Але, на жаль, його не можна накопичити, передати або взяти в кредит, тому важливо навчитися використовувати його 3 максимальною користю. Тайм-менеджмент (від англ. time management - «управління часом») - це набір правил, практик, навичок, інструментів і систем, спільне використання яких дозволяє більш ефективно використовувати свій час і, в перспективі, поліпшити якість життя [1]. Сис- 
тема управління часом складає поєднання процесів, інструментів, техніки і методів. Звичайне управління часом $є$ необхідністю в розвитку будь-якого проекту, оскільки визначає час завершення проекту і масштаб.

Управління часом - це дія або процес тренування свідомого контролю над кількістю часу, витраченого на конкретні види діяльності, при якому спеціально збільшуються еорективність і продуктивність [6]. Головною метою тайм-менеджменту $є$ робити якомога більше справ, цим самим мінімізувати часові витрати та знизивши рівень стресу людини.

Управляти часом та його правильно розподіляти - справа не дуже й складна. Але для цього потрібно вміти розставляти пріоритети, аби виконувати все $з$ максимальною ефективністю. Тому, як і будь-які інші процеси, таймменеджмент має свої основні принципи, на яких базується управління часом, зокрема: планування часу, боротьба з пожирачами часу, розстановка пріоритетів, правило Паретто, від складного до простого, не робити багато справ одночасно, почати планувати свій робочий день з обіду та відпочинку, дотримуватися чистоти на робочому місці, розбивати складні завдання на простіші, особиста мотивація та інші.

Ритм людини, яка живе в XXI столітті дуже швидкий та неспокійний. Ми всі щось не встигаємо. І, мабуть, кожен із нас міг би виконувати більше справ, якби трохи краще управляв собою і своїм часом. Для цього була створена величезна кількість методів та технік таймменеджменту, які допомагають нам краще та більше ефективно планувати та управляти своїм часом.

Перший метод - це «Метод Помідора», або «Система 25 хвилин». Його придумав Франческо Чирилло вкінці 1980-х років. Він використовував цей метод у ході підготовки до екзаменів. Назва цього методу пішла від кухонного таймеру, який був схожий на помідор, по якому Франческо засікав час [7]. Суть цього методу полягає в тому, що потрібно поставити таймер на 25 хвилин і під час цього періоду виконувати свою роботу, не відволікаючись ні на що. Після цього зробити п'ятихвилинну перерву і повторити процес знову. Через кожні 4 цикли - відпочинок 30 хвилин. Даний метод універсальний. Він підходить для будь-кого, і навіть для тих, хто не любить монотонну роботу. Адже в такому випадку процес розбивається на невеликі частини, які розділені відпочинком.

Існує ще такий метод тайм-менеджменту як «З’їжте жабу на сніданок». Що ж означає ця «жаба»? У кожного з насє неприємні справи. Для когось це дзвінок клієнту, для когось - розмова 3 босом. Так от, в термінології тайм-менеджменту неприємні справи (які тим не менш необхідні) називаються «жабами». I щоранку потрібно починати з ліквідації такої «жаби». Що це дає? Обробивши «жабу» з самого ранку, Ви відчуєте прилив сил і гарного настрою - більше нічого поганого не передбачається. Якщо відтягувати рішення неприємною завдання, це буде тиснути на психіку, посилюючи стрес і знижуючи продуктивність [8].

Метод слона. «Слонами» в таймменеджменті називають великі завдання і обсяги робіт. Наприклад, написання курсових робіт, будівництво будинків, вивчення іноземних мов та інші глобальні проекти. Однак слово «глобальний» лякає нас. Тому рекомендується ділити його на кілька фррагментів. Це називається «з"їсти слона» [8]. Тому коли ми ділимо завдання на підзадачі, воно не здається таким масштабним. Знижується ймовірність стресу та покращується ефективність роботи.

У зв'язку з пандемією COVID-19, навчальні заклади були змушені перевести навчання у дистанційний режим. Більшість студентів зіткнулися із проблемою організації їхнього часу. Для того, що ефективно розподілити свій необхідно дотримуватися вище згаданих методів і застосовувати їх на практиці. Також варто організувати робоче місце та простір, аби не відволікатися на дрібниці, вести щоденник із важливими подіями чи завданнями i, обов'язково, не забувати про відпочинок.

Для того, щоб перевірити на скільки ми раціонально використовуємо власний час в умовах дистанційної освіти, було проведено опитування серед студентів КПІ імені Ігоря Сікорського, в якому взяли участь 204 респондентів-студентів, серед яких 33\% - жінки та 67\% - чоловіки [9]. Вік учасників становив від 17 до 23 років. Найбільш поширений вік опитуваних - це 17-18 років (72,1\%). Опитування проводилось за допомогою Google Form [9]. Частка студентів, які навчаються на економічній спеціальності становить 85\%. Найпоширенішою серед економічних спеціальностей $є$ менеджмент та бізнес-адміністрування, серед інших спеціальностей взяли участь такі - право, фрізика, комп'ютерні системи та мережі. Період проведення опитування - квітень та травень 2021 року.

Перейдемо безпосередньо до результатів дослідження. Планування - це основа таймменеджменту. Планувати потрібно не тільки робочий час, а й особистий вільний час. Роз- 
почнемо з найпростішого запитання «Чи плануєте Ви список завдань на день?» Відповіді були різні: 47,1\% опитуваних в умовах дистанційної освіти планує свій день, роблячи це перед сном, або вранці; 13,2\% - роблять це іноді, якщо існує низка справ, які потрібно виконати в найближчий час, або ж планують не лише на день, а на тиждень; та 39,7\% осіб взагалі не планують свій день.

Способів планування часу існує безліч. Можна записувати список справ як в офлайн форматі, так і в онлайн фрорматі. Для першого варіанту можна використовувати різноманітні планери, щоденники, записники, блокноти, а для другого - існує безліч онлайн застосунків для телефрону, комп'ютера, де так само як і офрлайн, можна записувати свої задачі на день/тиждень/місяць. Серед опитуваних ми маємо такі результати: 34\% записують в блокнотах, щоденниках; 21\% - в онлайн фрорматі (нотатки в телефроні тощо); 43\% - не ведуть записи своїх справ. Певна частина опитуваних поєднує перший та другий варіант запису.

Досить поширеною проблемою серед молоді $є$ нестача сну. У середньому дорослі мають спати 7-9 годин на добу, аби мати достатньо сил. Тому наступним питанням нашого дослідження було «Яка в середньому тривалість Вашого сну?», на яке ми отримали наступні результати. Чотири п'ятих опитуваних (близько 80\%) має сон достатньої тривалості, і це означає, що їхній організм встигає відпочити та підготуватися до наступного дня. Однак інша частина осіб значно недосипає. Можливо це відбується через неправильний власний тайм-менеджмент.

Тому наступні показники будуть стосуватися того, де ж ми витрачаємо наш час, та чому його може не вистачати. У ході опитування було виявлено, що в середньому екранний час респондентів становить від 5 до 8 годин протягом дня (рис. 1). Виходячи 3 попередньо наведеного питання, слідує питання «Які програми в гаджетах Ви використовуєте найбільше?» Топ-5 програм становлять: Instagram, Telegram, TikTok, YouTube та Chrome. Наприклад, під час прийому їжі близько 40\% осіб гортає стрічку Instagram, ще частина - 24\% переглядають відео в TikTok та мабуть найбільш поширеною відповіддю була «дивлюсь відео в YouTube», що становить $57 \%$ від усіх опитуваних. Також серед молоді набуває популярність прослуховування підкастів, що дає змогу поєднувати приємне (прийом їжі) 3 корисним (отримання нової, цікавої інсрормації).

Безумовно, що людині необхідно розвиватися як інтелектуально, так і фрізично. Тому, щоб змінювати своє життя на краще, потрібно приділяти цьому трохи часу кожного дня. Опитані студенти в середньому приділяють близько 1 години на заняття спортом та 1-2 години (49,5\% від усієї кількості) - на саморозвиток.

Так як всі опитувані - студенти університету, то, відповідно, вони отримують певні домашні завдання. На запитання «Скільки час ви витрачаєте на домашні завдання (підготовка до семінарів, практик тощо)?» отримали такі відповіді: під час дистанційного навчання, через пандемію COVID-19, 40\% та $33 \%$ опитуваних витрачають на виконання 1-2 та 3-4 години відповідно, буває й так, що певні завдання потребують більше часу або уваги, тому близько $12 \%$ опитуваних готуються до семінарів, практик тощо понад

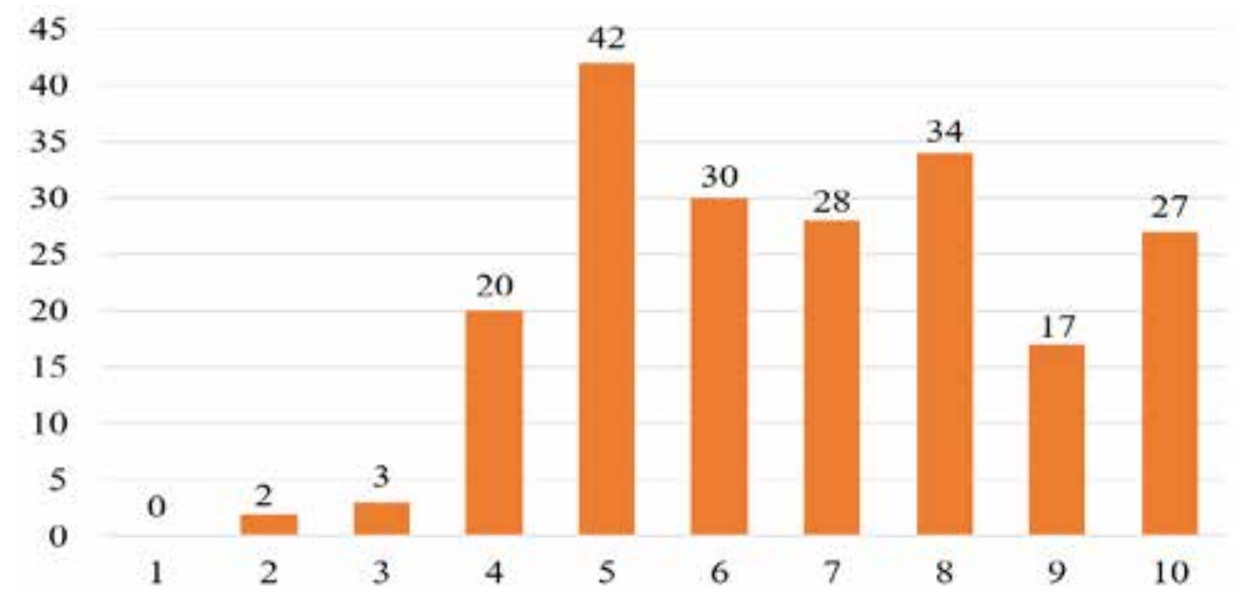

Рис. 1. Скільки в середньому становить Ваш екранний час протягом дня? (в год.)

Джерело: на основі власного дослідження 
4 години. На це може впливати й те, як часто вони відволікаються на чай або каву під час виконання домашніх завдань. Для цього було запропоновано шкалу від 1 до 5. «1» - роблю каву/чай до того, як сісти за робоче місце, та «5» - часто відволікаюсь на їжу/напої на кухні. У результаті виявилося, що більша частина опитуваних (85\%) дуже рідко відволікаються на каву/чай під час виконання завдань.

Також на те, як ефрективно ми використовуємо власний час, можуть впливати й інші чинники. Першою причиною. яка заважає виконувати всі заплановані справи - це неправильно розподілений час ( $30 \%)$ та соціальні мережі (26\%). Для того, щоб уникати будь-яких подразників, потрібно чітко зосереджуватися на поставленому завданні, а також додатково можна вжити заходів до їх обмеження на певний проміжок часу. Це може бути видалення чи блокування того чи іншого «пожирача часу», налаштувати систему оповіщення телефрону (комп'ютера) [10].

Для того, щоб оцінити на скільки учасники опитування раціонально розподіляють пріоритети серед списку поставлених задач, ми поставили студентам запитання «У першу чергу зранку Ви займаєтесь найбільш важливими справами?» Лише 26\% від усіх починають виконувати поставлені задачі 3 самого ранку (рис. 2). Варто зазначити, щоб ефективно використовувати власний час, доцільно розподіляти список справ на 4 категорії, такі як: важливі і термінові, важливі, але не термінові, термінові, але не важливі та не важливі і нетермінові. Максимум своєї уваги необхідно зосереджувати на категорії «важливі, але нетермінові», а от від четвертої краще зовсім відмовитися, оскільки це такі «пожирачі часу» [11].
Іноді ми чуємо, що часу в добі не вистачає, щоб виконати всі заплановані справи. Насправді, часу в добі завжди однаково 24 години. Напевно його не вистачає через те, що очікування і плани значно перебільшують наші можливості. У ході дослідження ми виявили, що 37\% опитуваним під час дистанційної освіти частково вистачає 24 годин в добі для виконання усіх справ, 45\% - повністю вистачає цього часу, а от $18 \%$ - не вистачає.

То що, ж робити з тими справами, які повинні бути виконаними до кінця дня, але так склалася ситуація і Ви ніяк не встигаєте? Було б доцільно попросити допомоги у інших, наприклад, у рідних, друзів тощо. Але часто людям дуже складно робити це навіть, коли дуже потрібно. За результатами близько 64\% дуже рідко просять про допомогу та намагаються зробити все власними силами. Або ж, існує ще один спосіб: делегування справ легких справ. Такий вид тайм-менеджменту дозволить зосередитися на більш важливих задачах.

Доволі частою проблемою серед людей $€$ прокрастинація. Прокрастинація - це перекладання справ на потім, на наступний день. Цей термін означає те, наприклад, коли ви пообіцяли собі або іншим щось зробити, але перекладаєте це спочатку на завтра, потім на післязавтра, і так триває безкінечно. Серед респондентів (понад 90\%), майже всі відкладають справи на потім. Це відбувається не через лінь, а через те, що існують різноманітні «подразники», тобто людина робить щось, але не те, що потрібно, цим самим, використовуючи неефективно час та втрачаючи його.

I останній показник це продуктивність. Респондентам було запропоновано шкалу від 1 до 10 із запитанням «Чи все Ви всти-

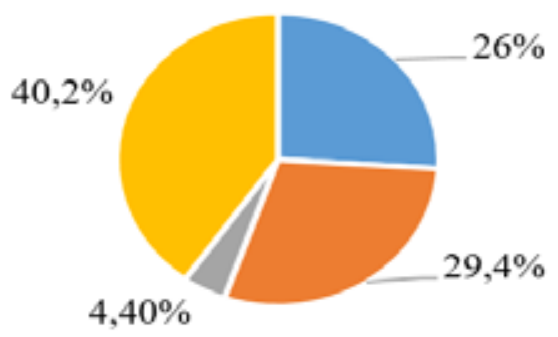

" Так, відразу починаю все виконувати
" Ні
" Залежить від ситуації
= Спочатку гортаю стрічку Instagram, бо іншої соц. мережі

Рис. 2. У першу чергу зранку Ви займаєтесь найбільш важливими справами?

Джерело: на основі власного дослідження 


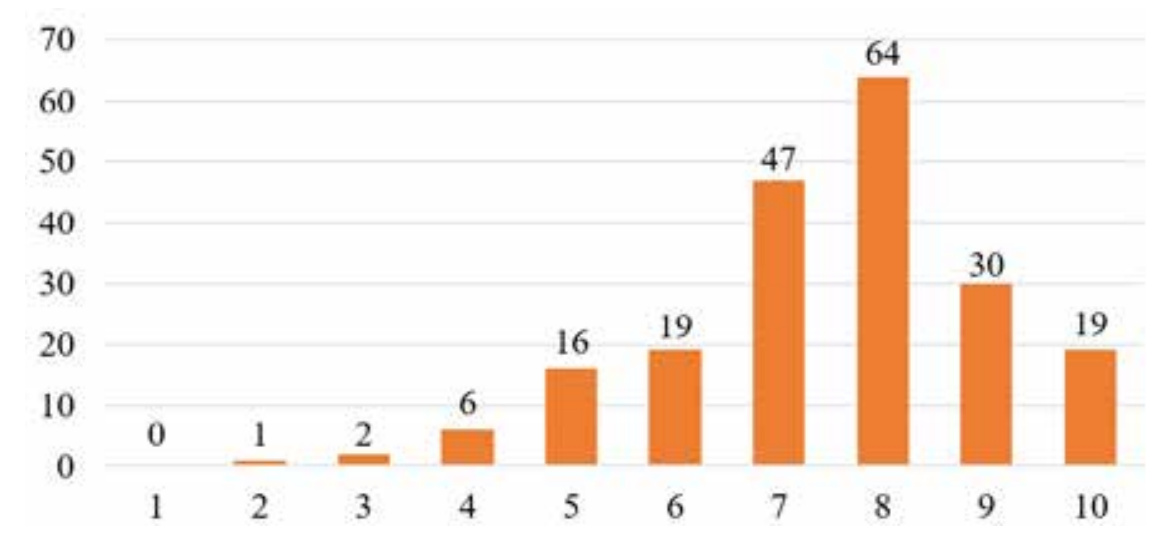

Рис. 3. Чи все Ви встигаєте за день? Оцініть за шкалою від 1 до 10

Джерело: на основі власного дослідження

гаєте за день» Результати показують, що під час дистанційного навчання студенти в більшості випадках встигають виконати усі справи (рис. 3). Існує така рекомендація, що для того, щоб протягом дня встигати більше, потрібно бути обережним з тим, як ви проводите свій час.

3 урахування проведеного дослідження, надаємо перелік рекомендацій, які зможуть підвищити ефективність тайм-менеджменту в умовах дистанційної освіти :

- плануйте час, використовуючи щоденники, записники гаджети;

- розставляйте пріоритети та виконуйте спершу найбільш важливі справи;

- не відкладайте справи на потім;

- чітко зосереджуйтесь на поставленому завданні і не відволікайтеся;

- обов'язково знаходьте час на відпочинок $\mathrm{Ta} \mathrm{COH}$.

Висновки. Підсумовуючи результати дослідження можна зробити висновок, що студенти розуміють важливість таймменеджменту протягом дня та намагаються правильно розподіляти час. Можливо деяким було б варто переглянути свій день, із точки зору управління часом та зробити висновки щодо того, як та куди вони витрачають свій час під час дистанційного режиму навчання. Тож, результати дослідження дозволяють нам зробити висновок, що тайм-менеджмент важливий у нашому житті, а особливо у період дистанційної освіти, у зв'язку з пандемією COVID-19. По-перше, для того, щоб жити повноцінним життям, знаходити час не тільки для роботи, але і для відпочинку. По-друге, для того, щоб ефективно розподіляти час на особистий і робочий, на вирішення важливих завдань і не дуже. По-третє, для того, щоб усвідомлювати свої цілі і взагалі життєві вчинки. По-четверте, для того, щоб мотивувати самого себе більш ефективно працювати і встигати все більше й більше.

\section{СПИСОК ВИКОРИСТАНИХ ДЖЕРЕЛ:}

1. Адаир Д. А. Искусство управлять людьми и самим собой. URL: https://www.e-reading-lib.com/bookreader. php/105005/dzhon-adair-iskusstvo-upravlyat-lyudmi-i-samim-soboy.pdf

2. Алюшина Н. О. Тайм-менеджмент: Мистецтво планувати та управляти своїм часом. Київ : Національна академія державного управління при Президентові України, 2008. 119 с.

3. Архангельский Г. А., Лукашенко М. А., Телегина Т. В., Бехтерев С. В. Тайм-менеджмент. Полный курс : учебное пособие / Под ред. Г.А. Архангельского. Москва : Альпина Паблишер, 2012. 311 с.

4. Куликова В. Н. Заставьте время работать на вас. Москва : ЗАО Центрполиграф, 2008. 192 с.

5. Брайан Т. Результативный тайм-менеджмент: эффрективная методика управления собственным временем / пер. с англ. А. Евтеева. Москва : СмартБук, 2007. 79 с.

6. Управление временем. URL: https://ru.wikipedia.org/wiki/\%D0\%A3\%D0\%BF\%D1\%80\%D0\%B0\%D0\%B2 \%D0\%BB\%D0\%B5\%D0\%BD\%D0\%B8\%D0\%B5_\%D0\%B2\%D1\%80\%D0\%B5\%D0\%BC\%D0\%B5\%D0\%BD\%D0 $\% \mathrm{~B} 5 \% \mathrm{D} 0 \% \mathrm{BC}$

7. 15 популярных техник тайм-менеджмента. URL: https://skillbox.ru/media/growth/15_populyarnykh_ tekhnik_taym_menedzhmenta/

8. Основні методи тайм-менеджменту. URL: http://sbm.pnu.edu.ua/2018/11/18/osnovni-metody-tajmmenedzhmentu/ 
9. Опитування на тему «Тайм-менеджмент одного дня». URL: https://forms.gle/XcGJqANNLwxWwnvQ8

10. Тайм-менеджмент, або мистецтво управління часом. URL: https://vseosvita.ua/library/tajm-menedzmentabo-mistectvo-upravlinna-casom-42519.html

11. Що таке тайм-менеджмент: особистий тайм-менеджмент або як управляти своїм часом. URL: https://blog.agrokebety.com/shcho-take-taym-menedzhment

\section{REFERENCES:}

1. Adair D. A. Iskusstvo upravlyat lyudmi i samim soboy [The art of managing people and yourself]. Retrieved from: https://www.e-reading-lib.com/bookreader.php/105005/dzhon-adair-iskusstvo-upravlyat-lyudmi-isamim-soboy.pdf (in Russian)

2. Alyushina N. O. (2008) Tajm-menedzhment: mystecztvo planuvaty ta upravlyaty svoyim chasom [Time-management: the art of planning and managing their time]. Kyiv: Nacionalna akademiya derzhavnogo upravlinnya pry Prezydentovi Ukrayiny. (in Ukrainian)

3. Arkhangel'skiy G. A., Lukashenko M. A., Telegina T. V., Bekhterev S. V. (2012) Taym-menedzhment. Polnyy kurs: uchebnoe posobie [Time management. Complete Course: Study Guide] / In G.A. Arkhangel'skogo (Eds). Moscow: Alpina Pablisher. (in Russian)

4. Kulikova V. N. (2008) Zastavte vremya rabotat na vas [Make time work for you]. Moscow: ZAO Tsentrpoligraf. (in Russian)

5. Brian T. (2007) Rezultativnyj tajm-menedzhment: jeffektivnaja metodika upravlenija sobstvennym vremenem [Effective time management: it is effective technique]/ per. z angl. A. Evteeva [trans. from eng A. Yevteyev]. Moscow: SmartBuck.

6. Upravlenie vremenem. Retrieved from: https://ru.wikipedia.org/wiki/\%D0\%A3\%D0\%BF\%D1\%80\%D0\%B0\% D0\%B2\%D0\%BB\%D0\%B5\%D0\%BD\%D0\%B8\%D0\%B5_\%D0\%B2\%D1\%80\%D0\%B5\%D0\%BC\%D0\%B5\% D0\%BD\%D0\%B5\%D0\%BC

7. 15 populyarnykh tekhnik taym-menedzhmenta. Retrieved from: https://skillbox.ru/media/growth/15_populyarnykh_tekhnik_taym_menedzhmenta/

8. Osnovni metody taim-menedzhmentu. Retrieved from: http://sbm.pnu.edu.ua/2018/11/18/osnovni-metodytajm-menedzhmentul

9. Opytuvannia na temu «Taim-menedzhment odnoho dnia». Retrieved from: https://forms.gle/XcGJqANNLwxWwnvQ8

10. Taim-menedzhment, abo mystetstvo upravlinnia chasom. Retrieved from: https://vseosvita.ua/library/ tajm-menedzment-abo-mistectvo-upravlinna-casom-42519.html

11. Shcho take taim-menedzhment: osobystyi taim-menedzhment abo yak upravliaty svoim chasom. Retrieved from: https://blog.agrokebety.com/shcho-take-taym-menedzhment 